\title{
Magnetotelluric imaging of the Neoproterozoic Rio Preto Belt and an Archean block in the basement of the Parnaíba and SanFranciscana basins, NE Brazil
}

\author{
Gonzalo Romero-Beltran ${ }^{*}$, Liliane P. Panetto ${ }^{1}$, Miguel Tupinambá2 ${ }^{2}$ Emanuele F. La Terra ${ }^{1}$ and Sergio L. \\ Fontes ${ }^{1},{ }^{1} \mathrm{ON},{ }^{2} \mathrm{UERJ}$. \\ Copyright 2021, SBGf - Sociedade Brasileira de Geofísica. \\ This paper was prepared for presentation during the $17^{\text {th }}$ International Congress of the Brazilian Geophysical Society held in Rio de Janeiro, Brazil, $16-19$ August 2021. \\ Contents of this paper were reviewed by the Technical Committee of the $17^{\text {th }}$ International Congress of the Brazilian Geophysical Society and do not necessarily represent any position of \\ the SBGf, its officers or members. Electronic reproduction or storage of any part of this paper for commercial purposes without the written consent of the Brazilian Geophysical Society is \\ prohibited.
}

\begin{abstract}
The Rio Preto belt (RPB) evolved around the São Francisco Craton, along other Neoproterozoic belts. Despite several geological, geochemical and petrophysical studies carried out in the area, the RPB is the least studied and understood in relation to the other belts. Its structural and tectonic knowledge is the key to understand the evolutionary history of the Paleozoic Parnaiba basin and the Mesozoic SanFranciscana basin. In this study we present a 3D resistivity model from the inversion of magnetotelluric (MT) data, to characterize the upper crust geoelectric behavior. The data were acquired from 17 MT soundings distributed in a NW-SE cross-section profile from an outcropping part of the Rio Preto Belt throughout the Mesozoic SanFranciscana Basin. In the NW sector of the profile, our model evidenced conductive sedimentary layers of the Parnaíba Basin underlying Sanfranciscana basin arenites and a homogeneous conductive domain (HCD) extending to depths greater than $15 \mathrm{~km}$. We interpret the HCD as a zone of crustal weakness with fluid circulation below the Parnaiba basin. The SE sector evidence the tectonic contact between the RPB metassedimentary rocks and the Archean Cristalândia do Piauí resistive block. The interpretation of the Archean block is constrained by the gravimetric model that shows a gravity high in the border of the Parnaíba basin. Subvertical shallow and deep conductors in the block represent folded graphite-rich metavolcano-sedimentary sequences described to the east of the MT section.
\end{abstract}

